\title{
Perbedaan De-astrigency Terhadap Lama Masa Simpan Buah Kesemek
}

\section{(The Different of De-astringency on Long-life Storage of Persimmon Fruit)}

\author{
Eko Setiawan $^{1^{*}}$ \\ ${ }^{1}$ Prodi Agroteknologi, Fakultas Pertanian, Universitas Trunojoyo Madura \\ Jl. Raya Telang, Kamal, Bangkalan, Jawa Timur, Indonesia, 69162 \\ *Email korespondensi: e_setiawan@trunojoyo.ac.id
}

Diterima 21 Agustus 2018/Disetujui 30 September 2018

\begin{abstract}
Oriental persimmon (Diospyros kaki L.) originated from and has mainly been cultivated in China, Korea, and Japan, and currently it is cultivated in Indonesia in Batu, Kuningan, and Brastagi regions. Success in propagating persimmon in Indonesia has been limited. The objective of the study was to determine low temperature to long-live storage of persimmon fruit. Spraying persimmon fruit with alcohol 95\% can remove astringency properties more quickly, but fruit quality becomes worse because of damage to the fruit cell wall, the skin flesh disorder and decay. Fruit with treatment spray alcohol $95 \%$ increased the decay until 50\% during two weeks postharvest. To maintain the quality of persimmons, need to spray with alcohol $70 \%$ for good quality.
\end{abstract}

Keywords: alcohol, astringency, fruit quality, persimmon.

\begin{abstract}
ABSTRAK
Kesemek oriental (Diospyros kaki L.) berasal dari dan sebagian besar telah dibudidayakan di Cina, Korea, dan Jepang, dan saat ini dibudidayakan di Indonesia di daerah Batu, Kuningan, dan Brastagi. Keberhasilan dalam menyebarkan kesemek di Indonesia masih terbatas. Tujuan dari penelitian ini adalah untuk menentukan suhu rendah untuk penyimpanan lama buah kesemek. Penyemprotan buah kesemek dengan alkohol 95\% dapat menghilangkan sifat astringency lebih cepat, tetapi kualitas buah menjadi lebih buruk karena kerusakan pada dinding sel buah, gangguan daging kulit dan pembusukan. Buah dengan perlakuan semprotan alkohol 95\% meningkatkan pembusukan hingga 50\% selama dua minggu pascapanen. Untuk menjaga kualitas kesemek, perlu disemprotkan dengan alkohol 70\% untuk kualitas yang baik.
\end{abstract}

Kata kunci: alkohol, astringency, kesemek, kualitas buah.

\section{PENDAHULUAN}

Diospyros kaki L. dikenal dengan sebutan Oriental (Chinese/Japanese) persimmon atau kesemek merupakan keluarga Ebenaceae, asal penyebaran Jepang dan China (Khan et al., 2016) kemudian dibudidayakan ke berbagai belahan dunia seperti Brazil, Italia dan termasuk Indonesia. Santosa et al. (2005), melaporkan lokasi penanaman kesemek di Indonesia, khususnya di dataran tinggi seperti daerah Malang, Majalengka, Garut, Kuningan, Karo, Toba serta Solok, tetapi saat ini juga dikembangkan di daerah Cisurupan, Garut, Ciloto, Boyolali, Temanggung, Magelang, dan Magetan. Hal tersebut berarti tanaman kesemek punya peluang untuk dibudidayakan secara luas di Indonesia dan perlu peningkatan kualitas buah supaya disukai oleh konsumen (Setiawan, 2017).

Kesemek identik dengan buah yang mengandung tanin dan rasa sepat (Heras et al., 2016). Sifat astringency berkaitan dengan kandungan tanin dalam buah (Novillo et al., 2015). Beberapa metode untuk menghilangkan sifat astringency yaitu dengan perendaman buah kesemek pada larutan kalsium oksida selama lima hari (Santosa et al., 2005). Salah satu kelemahan penggunaan larutan kalsium oksida adalah warna putih dari kapur yang menutupi kulit, warna buah menjadi kurang menarik bagi konsumen di Indonesia. Kedua, dengan penggunaan kalsium oksida meyebabkan konsumen mengalami kesulitan untuk membedakan perubahan warna buah, dari buah warna hijau saat masih keras menjadi berwarna kuning jika sudah lunak. Konsumen membedakan tingkat kekerasan dengan cara memencet atau menekan buah, dan hal tersebut akan merusak kualitas buah kesemek. Sebelumnya Setiawan (2014) melaporkan penyemprotan buah kesemek dengan alkohol dapat menghilangkan sifat astringency. Tetapi belum diketahui efek peningkatan konsentrasi alkohol diatas $70 \%$. Penyimpanan pada suhu rendah dapat memperpanjang umur simpan dari buah karena mengurangi aktivitas respirasi dan produksi etilen, tetapi kulit buah menjadi lembek dan warnanya menjadi gelap (Liamnimitr et al., 2018). Proses menghilangkan sifat astringency buah 
kesemek menggunakan penyemprotan alkohol di Indonesia masih relatif baru meskipun di beberapa negara penghasil kesemek sudah dilakukan. Tujuan dari penelitian ini adalah untuk mengetahui umur simpan dan kualitas buah yang disemprot berbagai konsentrasi alkohol untuk menghilangkan sifat astringency.

\section{METODE PENELITIAN}

Penelitian dilaksanakan di Laboratorium Produksi Prodi Agroekoteknologi, Fakultas Pertanian, Universitas Trunojoyo pada Juni-Juli 2016. Buah kesemek diperoleh dari kebun petani kesemek yang ada di Batu, Malang. Buah kesemek dipanen setelah masak fisiologis yaitu warnanya berubah dari hijau menuju kuning atau orange. Kesemek dikelompokkan berdasarkan warna kulit yang menunjukkan tingkat kemasakan fisiologisnya yaitu hijau kekuningan (A), kuning (B) dan coklat kemerahan (C) pada Gambar 1a. Selanjutnya buah diberi perlakuan seperti di bawah ini:

1) A70: buah masak fisiologis warna hijau kekuningan disemprot alkohol 70\% (Gambar 1b).

2) A95: buah masak fisiologis warna hijau kekuningan disemprot alkohol $95 \%$.

3) B70: buah masak fisiologis warna kuning disemprot alkohol $70 \%$.

4) B95: buah masak fisiologis warna kuning disemprot alkohol $95 \%$.

5) C70: buah masak fisiologis warna kuning kemerahan disemprot alkohol $70 \%$.

6) C95: buah masak fisiologis warna kuning kemerahan disemprot alkohol 95\%.

7) Kapur: buah masak fisiologis warna kuning direndam dengan air kapur, meurut Setiawan (2014).

8) Kontrol: buah warna hikau kekuningan dan tidak diberikan apa-apa.

Kelompok kesemek yang diberi perlakuan kemudian dibungkus dengan kertas koran, selanjutnya dimasukkan ke dalam kantong plastik dan diikat serapat mungkin sehingga udara tidak bisa keluar masuk (Gambar 1c). Setiap bungkus terdiri dari 3 sampel buah. Penelitian diulang sebanyak tiga kali. Semua buah disimpan kedalam lemari pendingin dengan suhu $15{ }^{\circ} \mathrm{C}$. Setiap minggu kesemek sesuai perlakuan diukur tingkat kekerasan buah dengan penetrometer dan juga diukur kadar gula $\left({ }^{\circ}\right.$ Brix) diukur dengan hand refractometer (PAL-1, Atago, Tokyo Tech). Data yang diperoleh selanjutnya dianalisis menggunakan ANOVA. Apabila terdapat interaksi atau pengaruh perlakuan maka dilanjutkan menggunakan Uji Jarak Duncan (UJD) $5 \%$.

\section{HASIL DAN PEMBAHASAN}

Buah kesemek mempunyai dua kultivar yaitu nonastringency dan astringency. Pada buah tipe astringency memerlukan beberapa perlakuan pascapanen dan bisa dimakan setelah daging buahnya mengalami pelunakan (Wei et al., 2013). Perlakuan de-astringency merupakan proses merubah tanin terlarut menjadi tidak larut seperti perlakuan $\mathrm{CO}_{2}$ atau ethanol, dan acetaldehyde (Guan et al., 2015). Proses penghilangan sifat astringency pada kesemek 'Mopanshi' dan 'Eshi 1' dilaporkan lebih cepat terjadi pada perlakuan suhu udara $40{ }^{\circ} \mathrm{C}$ (Guan et al., 2015). Banyak metode menghilangkan sifat astringency, salah satu yang paling populer adalah dengan aktifasi alkohol dehidrogenase (Edagi and Kluge, 2009). Pada Gambar 2 adalah perubahan tingkat kemasakan buah kesemek yang ditandai oleh perubahan warna kulit buah, daging buah serta peningkatan kadar gula. Peningkatan kadar gula berhubungan erat dengan tingkat kemasakan buah kesemek (Ozer et al., 2013). Kadar gula optimal pada tingkat kemasakan 5-6 kemudian perlahan-lahan menurun seiring tingkat kematangan menuju kearah pembusukan. Kisaran kandungan gula pada buah kesemek antara 24.0-27.5 ${ }^{\circ}$ Brix. Pemberian ethanol dapat menghilangkan sifat astringency dalam waktu 2 hari yang ditandai dengan perubahan warna kulit buah kesemek (Yamasaki et al., 2017); serta kandungan volatil buah dalam waktu sehari setelah diberikan penyemprotan alkohol (Martineli et al., 2013).

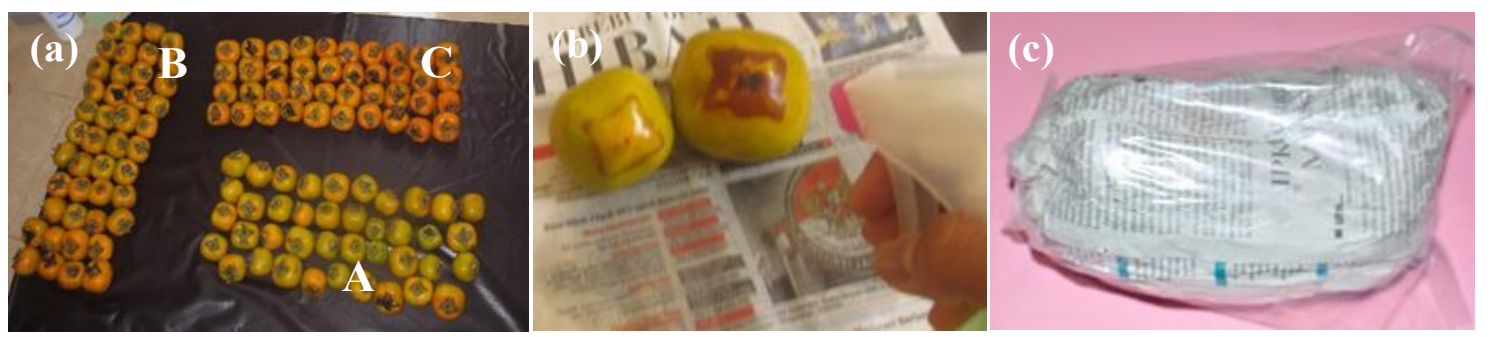

Gambar 1. Sebelah kiri: pengelompokan buah berdasarkan warna buah yaitu A: hijau kekuingan, B: kuning, dan C: coklat kemerahan (a), tengah: disemprot alkohol sesuai perlakuan (b), dan sebelah kanan: dibungkus koran kemudian dimasukkan plastik (c). 


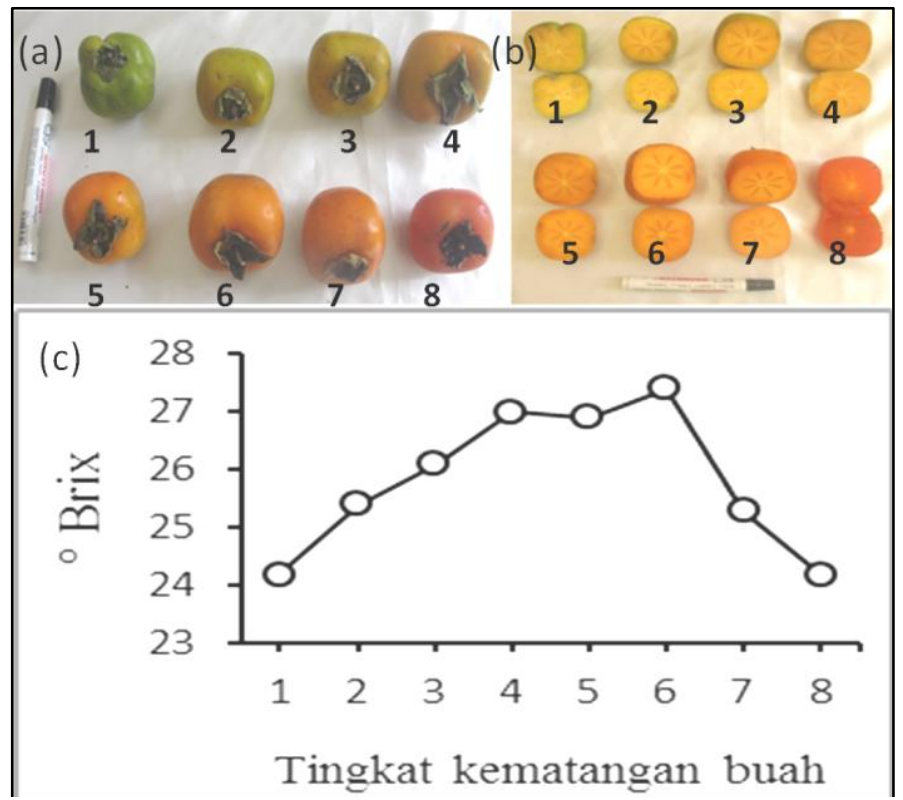

Gambar 2. Tingkat kemasakan buah dengan warna kulit yang berbeda (a), warna daging buah berdasarkan warna kulit (b), dan perubahan tingkat kemanisan daging buah berdasarkan kematangan fisiologis kulit buah (c).

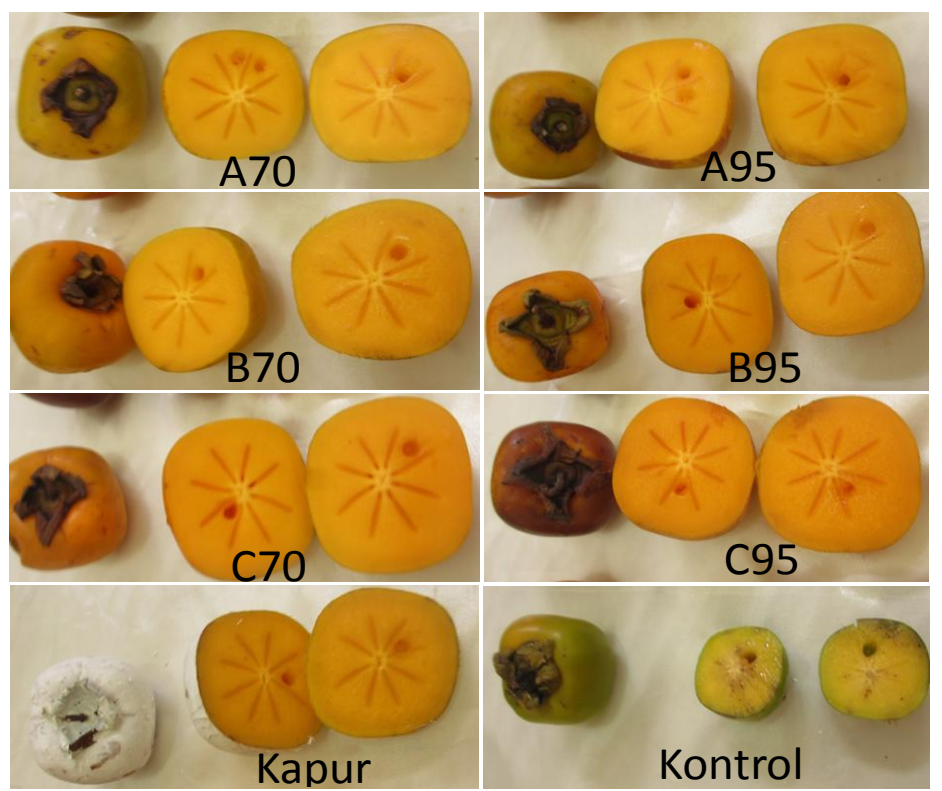

Gambar 3. Warna buah kesemek pada pengamatan minggu ke-1.

Pada minggu ke-2 tampilan B70 masih segar dan bagus, tetapi pada perlakuan B70 dan B95 sebanyak 50\% dalam kondisi busuk. Pada Gambar 3 dan Gambar 5 menunjukkan pada perlakuan C95 buah mengalami pelunakan yang cepat dan cepat busuk. Perubahan tingkat kekerasan buah kesemek berkaitan dengan tingkat kematangan (Wei et al., 2013). Hasil penelitian menunjukkan pada pengamatan minggu ke-3, perlakuan B70 memberikan hasil terbaik dengan warna daging buah cerah, segar dan kulit bersih. Hal tersebut berarti masa simpan kesemek yang kehilangan sifat astringency bisa mencapai 21 hari, ini sesuai dengan Yamasaki et al. (2017) yang menyatakan masa simpan bisa mencapai 18.9-20.7 hari untuk 'Taigetsu' dan 21.7-23.0 hari untuk 'Taiten'. Pada perlakuan kontrol menunjukkan warna kuning kehijauan, daging buahnya mengeluarkan banyak air, menghasilkan aroma alkohol, tepi buah lembek dan berwarna hijau. Pada buah kesemek dengan perlakuan C70 dan C95 menunjukkan kulit buah mengkerut, warnanya menjadi coklat kehitaman dan daging buahnya orange kemerahan yang diduga terjadi chilling injury (Gambar 4 dan 5). Chilling injury pada buah kesemek terjadi jika disimpan di bawah suhu $11{ }^{\circ} \mathrm{C}$ dengan gejala pelunakan daging buah dan perubahan warna menjadi gelap (Besada et al., 2008). Perubahan warna menjadi gelap juga dilaporkan terjadi pada kesemek tipe non-astringency selama proses penyimpanan akibat terjadinya chilling injury 


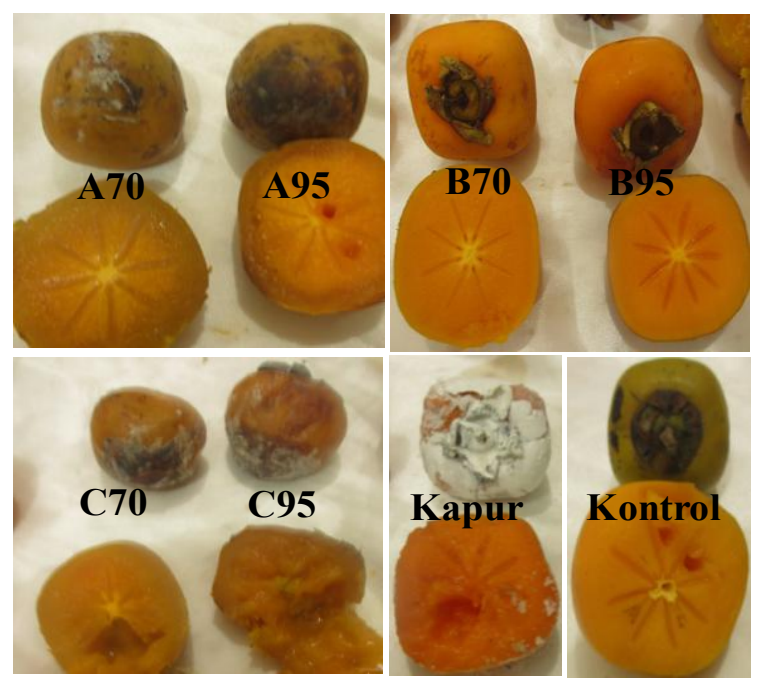

Gambar 4. Warna buah kesemek yang disimpan sampai dengan minggu ke-3.

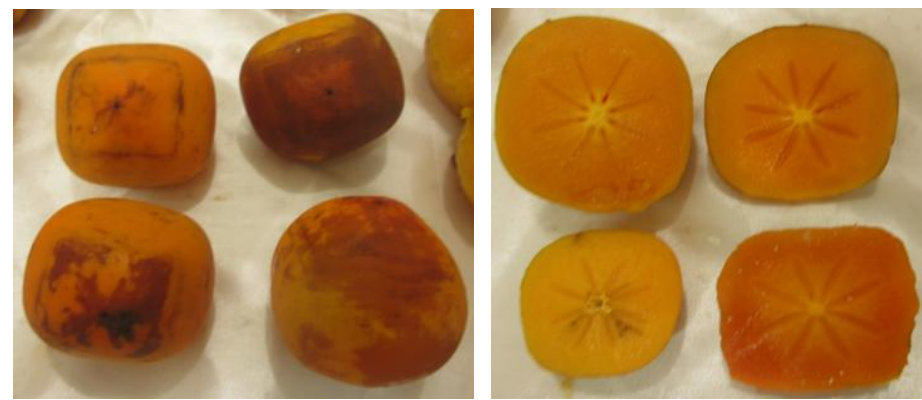

Gambar 5. Warna kulit buah menjadi gelap dan kecoklatan dan daging buah menjadi lunak mengarah ke pembusukan.

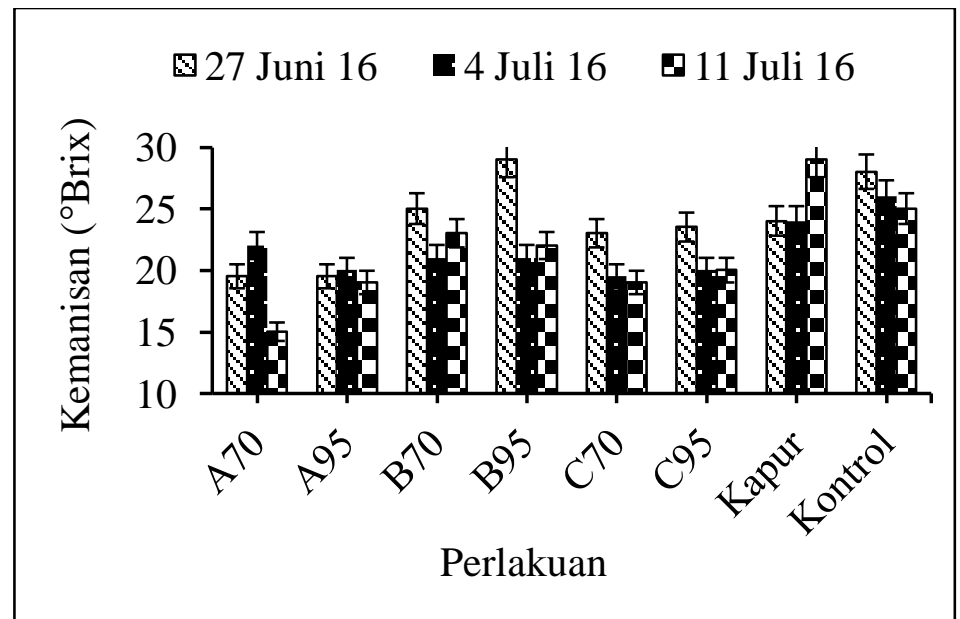

Gambar 6. Perubahan kandungan gula $\left({ }^{\circ}\right.$ Brix $)$ antar perlakuan selama penyimpanan. 


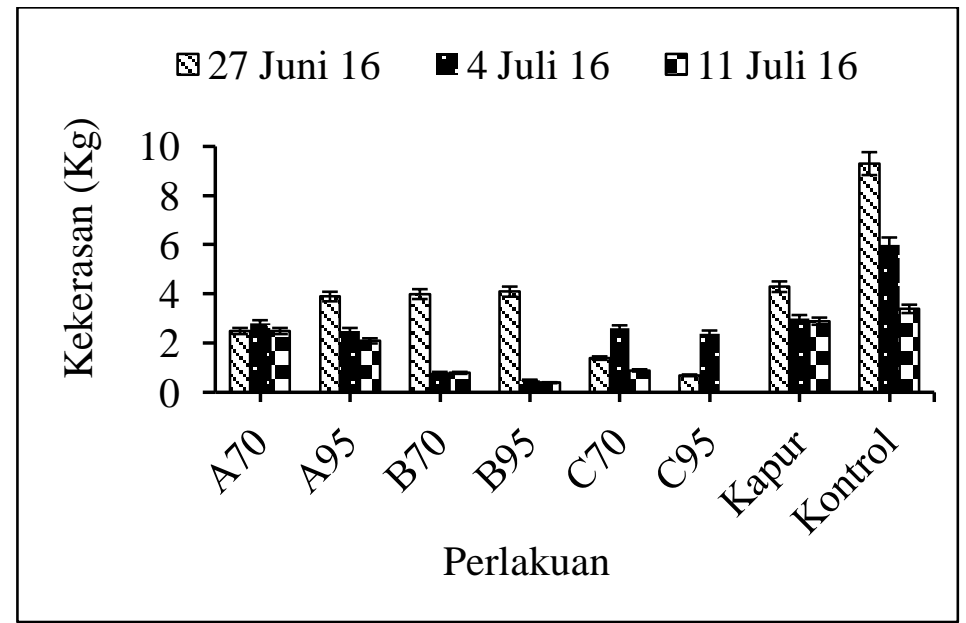

Gambar 7. Perubahan tingkat kekerasan buah $(\mathrm{Kg})$ antar perlakuan selama penyimpanan.

(Çandir et al., 2010). Pelunakan kulit buah kesemek yang lebih cepat serta perubahan warna menjadi coklat kehitaman kemungkinan diduga karena pengaruh penyimpanan buah pada kondisi suhu lemari pendingin $15^{\circ} \mathrm{C}$. Suhu yang dingin lebih cepat mempengaruhi pelunakan buah terutama setelah hilangnya sifat astringency sehingga memperpendek umur simpan buah (Ozer et al., 2013).

Perlakuan penyemprotan buah kesemek dengan alkohol $95 \%$ memberikan hasil penurunan tanin yang paling tinggi yaitu ditandai dengan lunaknya daging buah kesemek. Besada et al. (2013) melaporkan bahwa adanya acetaldehyde berimplikasi menghilangkan sifat astringency pada kesemek. Tetapi disisi lain produksi etanol dan acetaldehide sangat mempengaruhi kualitas buah, dimana kandungan acetaldehyde yang tinggi menyebabkan kerusakan pada dinding sel buah dan merusak rasa buah (Tessmer et al., 2016). Diduga penyemprotan dengan alkohol $95 \%$ pada buah kesemek menyebabkan perubahan struktur anatomi mesocarp akibat penurunan kandungan jarak intrasel serta pektin di dalam sel. Hal inilah yang menyebabkan permukaan kulit buah dengan penyemprotan alkohol $95 \%$ mengalami pengerutan. Kondisi buah yang mengalami kerusakan dan busuk terutama pada C70 dan C95 serta kapur pada minggu ke-3 mendukung penelitian Ozer et al., (2013).

Rata-rata kandungan gula pada buah warna hijau kekuningan (A) meningkat sampai minggu ke-2 kemudian turun pada minggu ke-3 (Gambar 6). Sedangkan pada buah warna kuning (B) dan warna kuning kemerahan (C) memiliki kandungan gula tertinggi pada minggu ke-1. Hal tersebut artinya pada minggu ke-1 sudah terjadi penurunan sifat astringency. Sebaliknya pada perlakuan kapur kandungan gula meningkat dari minggu ke-1 sampai minggu ke-3. Peningkatan kandungan gula sampai minggu ke-3 pada pemberian kapur berarti penurunan astringency berjalan lebih lambat dari penyemprotan alkohol. Kandungan gula, glukosa, sukrosa dan fruktosa pada buah kesemek berkisar 1-8g/100g FW (Bubba et al., 2009).

Pengamatan tingkat kekerasan buah masih tinggi pada minggu ke-1 selanjutnya mengalami penurunan pada minggu ke-3. Penurunan kekerasan buah tercepat terjadi pada penyemprotan dengan alkohol 95\%, baik pada perlakuan A95, B95, maupun C95. Artinya penyemprotan dengan alkohol $95 \%$ dapat menghilangkan sifat astringency lebih cepat sehingga buah lebih cepat lunak dan masak. Tetapi pemberian konsentrasi alkohol yang tinggi menyebabkan permukaan buah rusak dan mengkerut sehingga minggu ke-2 dan ke-3 banyak buah yang busuk. Pada perlakuan kontrol minggu ke-1, kekerasan buah paling tinggi yaitu dua kali lipat dibandingkan dari semua perlakuan, hal ini menunjukkan kontrol tidak mengalami penurunan astringency pada minggu ke-1 tetapi baru pada minggu ke-3. Hal tersebut berarti kekerasan buah pada perlakuan kontrol kondisinya sama dengan penyemprotan alkohol minggu ke-1 (Gambar 7). Dapat disimpulkan bahwa penyemprotan buah dengan alkohol bisa melunakkan buah atau menghilangkan sifat astringency tiga kali lebih cepat dari kondisi normal tanpa perlakuan (kontrol).

\section{KESIMPULAN}

Penyemprotan alkohol dengan konsentrasi 95\% dapat menghilangkan sifat astringency lebih cepat, tetapi ualitas buah menjadi jelek karena terjadi kerusakan dinding sel buah sehingga kulitya mengkerut dan busuk lebih cepat. Untuk menjaga kualitas buah kesemek perlu penyemprotan alkohol dengan konsentrasi $70 \%$ supaya sifat astrigency turun tetapi kualitas tetap terjaga.

\section{DAFTAR PUSTAKA}

Besada, C., A. Salvador, L. Arnal, J.M. Martinez-Javega. 2008. Hot water treatment for chilling injury reduction of astringent 'Rojo Brillante' persimmon at different maturity stages. Horticulture Science. 43(7):2120-2123.

Besada, C., G. Sanchez, A. Salvador, A. Granell. 2013. Volatile compounds associated to the loss of astringency in persimmon fruit revealed by untargeted GC-MS analysis. Metabolomics 9:157172. 
Bubba, M. Del, E. Giordani, L. Pippucci, A. Cincinelli, L. Checchini, P. Galvan. 2009. Changes in tannins, ascorbic acid and sugar content in astringent persimmons during on-tree growth and ripening and in response to different postharvest treatments. J. Food Compos. Anal. 22:668-677.

Çandir, E., A.E. Özdemir, M. Kaplankiran, T.H. Demirkeser, E. Yildiz. 2010. Storage life of non-astringent persimmons grown in the eastern Mediterranean. New Zeal. J. Crop Hortic. Sci. 38(1):1-6.

Edagi, F.K., R.A. Kluge. 2009. Removal of astringency in persimmon fruits: a biochemical, physiological and technological view. Ciência Rural 39(2):585-594.

Guan, C., L. Chen, W. Chen, R. Mo, Q. Zhang, X. Du, Z. Luo. 2015. SSAP analysis reveals candidate genes associated with deastringency in persimmon (Diospyros kaki Thunb.) treated with $40{ }^{\circ} \mathrm{C}$ water. Tree Genet. Genomes 11(20):1-13.

Heras, R.M.L., J.C. Amigo-Sánchez, A. Heredia, M.L. Castelló, A. Andrés. 2016. Influence of preharvest treatments to reduce the seasonality of persimmon production on color, texture and antioxidant properties during storage. CyTA - J. Food. 14(2):333-339.

Khan, N., N. Shah, F. Bibi, S. Zeb, M. Khan, J. Iqbal, U. Anwar. 2016. Post-harvest life of Persimmon (Diospyros kaki L.) as affected by coating materials and storage intervals. Pure Appl. Biol. 5(4):963-970.

Liamnimitr, N., M. Thammawong, C. Techavuthiporn, K. Fahmy, T. Suzuki, K. Nakano. 2018. Optimization of bulk modified atmosphere packaging for long-term storage of 'Fuyu' persimmon fruit. Postharvest Biol. Technol. 135:1-7.

Martineli, M., A.A.R. Alves, G.M. de Figueiredo, C.M. de Rezende, M.J. de O. Fonseca. 2013. Persimnion cy.
"Mikado": analysis of volatile componnds in astringent and astringency removal. Cienc. Rural 43(8):1516-1521.

Novillo, P., A. Salvador, P. Navarro, C. Besada. 2015. Sensitivity of astringent and non-astringent persimmon cultivars to flesh disorders induced by mechanical damage. Acta Hort. 1079: 605-610.

Ozer, M.H., B. Akbudak, I. Altioglu. 2013. Postharvest quality of 'Hachiya' astringent persimmons (Diospyros kaki L.) as affected by hot water treatment and modified atmosphere packaging. Ital. J. Food Sci. 25: 57-63.

Santosa, E., N. Sugiyama, M. Nakata, S. Kawabata, N. Kubota. 2005. Cultivation of the Japanese persimmon in West Java, Indonesia. Jpn. J. Trop. Agr. 49(3): 220-226.

Setiawan, E. 2014. Perbaikan kualitas buah kesemek dengan penyemprotan alkohol. Agrovigor 7(2): 121-125.

Setiawan, E. 2017. Efektivitas pemberian IAA, IBA, NAA, dan Root-up pada pembibitan kesemek. J. Hort. Indones. 8(2): 97-103.

Tessmer, M.A., B. Appezzato-da-Glória, R.A. Kluge. 2016. Astringency in Giombo persimmon and its relationship with the harvest time. Rev. Ceres 63(5): 1-9.

Wei, X., F. Liu, Z. Qiu, Y. Shao, Y. He. 2013. Ripeness classification of astringent persimmon using hyperspectral imaging technique. Food Bioprocess Technol. 1-10.

Yamasaki, A., H. Yakushiji, H. Iwamoto, A. Azuma, H. Sugiura. 2017. Optimum conditions for on-tree ethanol-sticker treatment for astringency removal in 'Taigetsu' and 'Taiten' persimmons. Japanese Soc. Hortic. Sci. 1-7. 